MY APPROACH

\title{
How we process trephine biopsy specimens: epoxy resin embedded bone marrow biopsies
}

\author{
T Krenacs, E Bagdi, E Stelkovics, L Bereczki, L Krenacs
}

J Clin Pathol 2005;58:897-903. doi: 10.1136/icp.2004.023788

Improved cytomorphology of semithin resin sections over paraffin wax embedded sections may be important in diagnostic haematopathology. However, resin embedding can make immunohistochemical antigen detection or DNA isolation for clonal gene rearrangement assays difficult. This review describes the processing of bone marrow biopsies using buffered formaldehyde based fixation and epoxy resin embedding, with or without EDTA decalcification. Traditional semithin resin sections are completely rehydrated after etching in home made sodium methoxide solution. Resin elimination allows high resolution staining of tissue components with common histological stains. Efficient antigen retrieval and the Envision-HRP system permit the immunohistological detection of many antigens of diagnostic relevance, with retention of high quality cytomorphology. Furthermore, DNA can be extracted for clonality analysis. The technique can be completed within a similar time period to that of paraffin wax processing with only $\sim 30 \%$ increase in cost. This technique has been used for diagnosis in over 4000 bone marrow biopsies over the past 14 years. By meeting traditional and contemporary demands on the haematopathologist, it offers a powerful alternative to paraffin wax processing for diagnosis and research.

See end of article for authors' affiliations

Correspondence to: Dr L Krenacs, Laboratory of Tumour Pathology and Molecular Diagnostics, Institute for Biotechnology, Bay Zoltan Foundation for Applied Research, $\mathrm{H}-6726$ Szeged, Derkovits fasor 2, Hungary; krenacsl@

hotmail.com

Accepted for publication 2 December 2004
B one marrow trephine biopsies are essential when clinical data raise the suspicion of haematological disorders in which the diagnostic assessment of in situ tissue architecture, cellularity, and immunophenotyping can be decisive. ${ }^{1}$ Bone marrow histology is also important for lymphoma staging, follow up, and residual disease detection and for detection of bone marrow involvement by metastatic tumours. ${ }^{1-3}$ Because the recent histopathological classification of haematological disorders is based on the consideration of morphological, immunophenotypical, and genetic features, sample preparation for bone marrow archiving can be a crucial issue. ${ }^{4}$ Therefore, the ideal diagnostic management of bone marrow biopsies should support good cytomorphology and histotopography, and at the same time protect proteins for immunohistochemistry and DNA for genetic studies. In addition, the diagnostic procedure should be completed within a reasonable turnaround time and without exceeding a justifiable budget.
There has been a variety of approaches used for bone marrow trephine biopsy processing including frozen sections, and diverse fixation, decalcification, and embedding protocols. Haematopathologists have to be familiar with the benefits and limitations of these techniques to make their best choice. Until now, formaldehyde fixation and ethylenediamine tetraacetic acid (EDTA) decalcification have been found to offer the best compromise for preserving both morphology and molecular targets reasonably well, allowing consistent in situ detection of proteins and polymerase chain reaction (PCR) amplification of DNA for diagnosis. ${ }^{3-8}$ The use of resin embedded semithin sections results in improved cytomorphology compared with that seen in paraffin wax embedded sections. ${ }^{9-11}$ However, the polymerised resin usually hinders access of staining reagents to tissue molecules and the technology may require extra costs and skills. $^{12}$

\begin{abstract}
"The ideal diagnostic management of bone marrow biopsies should support good cytomorphology and histotopography, and at the same time protect proteins for immunohistochemistry and DNA for genetic studies"
\end{abstract}

We have set up a technique using formaldehyde fixation and epoxy resin embedding of bone marrow trephine biopsy specimens (Durcupan ACM; Fluka, Basel, Switzerland), with or without EDTA decalcification. The resin can be completely removed from the sections by etching with no adverse effects, so that rehydrated sections are suitable either for standard histological staining, immunohistochemistry, or DNA isolation. The combination of heat induced epitope retrieval, a selected antibody panel, and sensitive immunolabelling permits reliable immunodetection of a full range of antigens for diagnostic bone marrow pathology. The technique, which has been gradually improved in the light of the evolution of diagnostic classifications and antigen retrieval technology, has been used for diagnosing over 4000 bone marrow biopsies over the past 14 years. Here, we describe our protocol as an alternative approach for bone marrow pathology. Using a resin often used in electron microscopy, this technique fulfils traditional and recent diagnostic needs because it

Abbreviations: DAB, 3,3'-diaminobenzidine tetrahydrochloride; EDTA, ethylenediamine tetraacetic acid; HRP, horseradish peroxidase; PCR, polymerase chain reaction 

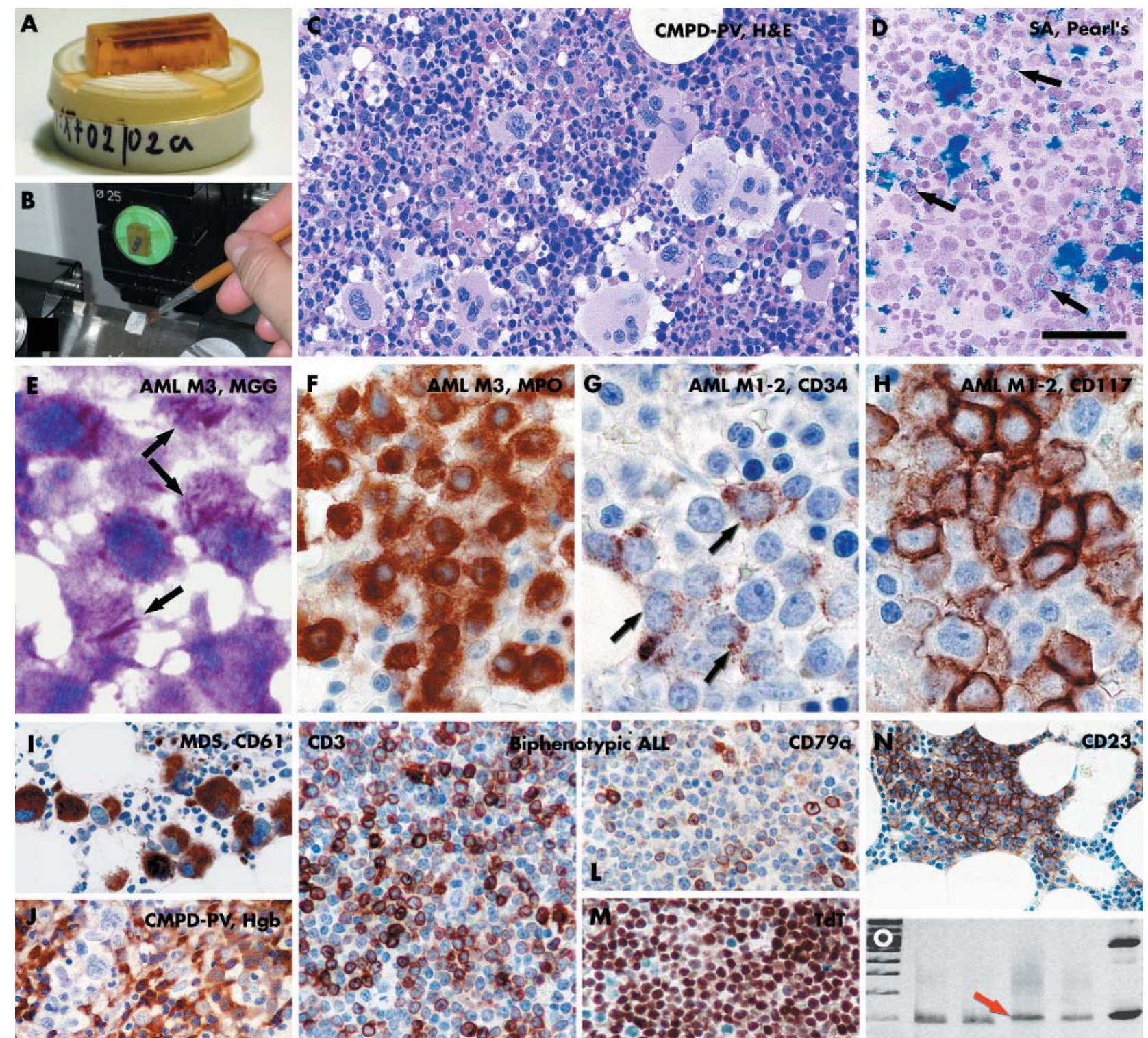

notypic ALP
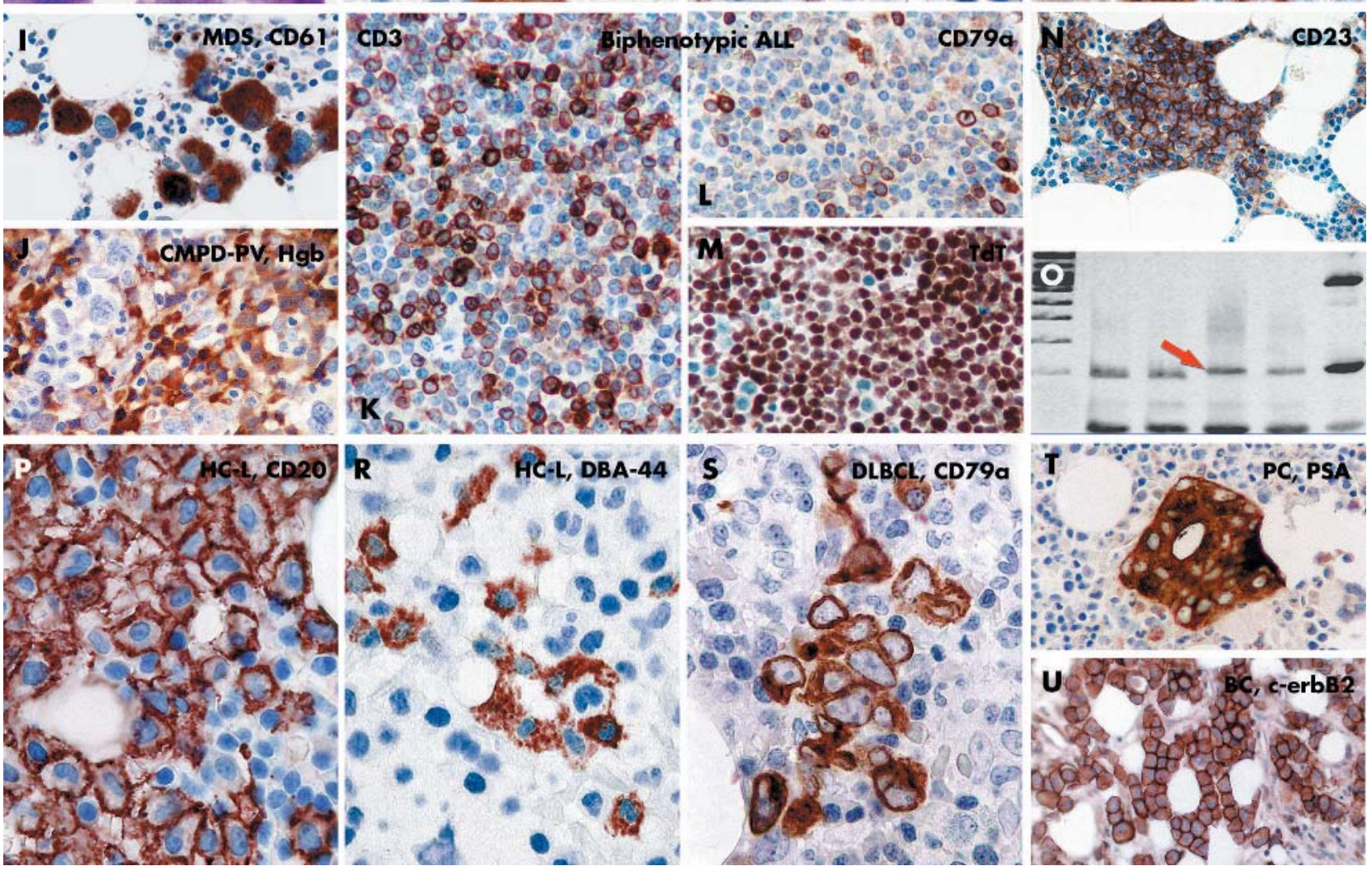

Figure 1 (A) Resin block of a bone marrow trephine stuck on to a labelled plastic stub. (B) Semithin sections are cut with a rotary microtome using a tungsten carbide edged knife. (C) Erythroid and megakaryocytic hyperplasia in chronic myeloproliferative disease (CMPD) polycythaemia vera (PV) using haematoxylin and eosin staining. Note the excellent cytomorphology and the absence of shrinkage artefacts. (D) Haemosiderin particles stained with Perls' Prussian blue in ring sideroblasts (arrows) of sideroblastic anaemia. (E) Auer rods (arrows) revealed with May-Grunwald-Giemsa in promyelocytic leukaemia, in undecalcified resin sections. (F) Promyelocytes of acute myeloid leukaemia (AML) FAB M3 stained for myeloperoxidase. (G) Granular cytoplasmic staining for CD34 (arrows) and (H) membrane staining for CD117 (c-kit) in myeloblastic tumour cells of AML FAB M1-2. (I) Increased numbers of immature megakaryocytes stained for CD61 in myelodysplastic syndrome. (J) Increased numbers of erythroid elements stained for haemoglobin A in CMPD PV. Biphenotypic acute lymphoblastic leukaemia stained for (K) CD3, (L) CD79a, and (M) terminal deoxynucleotidyl transferase. (N) Interstitial colony of neoplastic lymphocytes in B cell chronic lymphocytic leukaemia/small lymphocytic lymphoma stained for CD23 
supports high resolution immunostaining and reliable gene amplification assays in addition to providing superb cytomorphology.

\section{BONE MARROW PROCESSING AND STAINING Epoxy resin embedding}

Bone marrow trephine biopsies are fixed in $4 \%$ buffered formaldehyde supplemented with methanol and glucose ${ }^{13}$ (Schaefer's fixative; table 1). The normal duration of fixation is six to 10 hours, but it may be as long as 72 hours in the case of postage in formalin from a district hospital. Trephine biopsy specimens, ideally of $20-40 \mathrm{~mm}$, are cut into no longer than $10 \mathrm{~mm}$ pieces and either processed directly into the resin or decalcified, at least partly, in a mixture of $4 \%$ buffered formaldehyde and 10\% disodium-EDTA dihydrate (Sigma, St Louis, Missouri, USA) at $60^{\circ} \mathrm{C}$, for $16-24$ hours. Half of the biopsy is processed routinely into paraffin wax blocks for consultation purposes, and the other half is embedded in epoxy resin. For resin embedding, biopsy samples are dehydrated (for example, in an LKB Ultroprocessor; Bromma, Sweden), using a graded series of ethanol $(50 \%, 70 \%, 96 \%, 2 \times 96 \%$, and $2 \times$ absolute), then acetone, and finally equal parts of acetone and Durcupan ACM (Fluka), for 15 minutes each. The freshly prepared resin mix is composed of $12.2 \mathrm{~g}$ epoxy monomers, $10.0 \mathrm{~g}$ hardener (these components can be stored as a mixture for one month), $0.6 \mathrm{~g}$ accelerator, and $0.3 \mathrm{~g}$ plasticiser. Infiltration of the samples with the resin mix at $50^{\circ} \mathrm{C}$ for 40 minutes is followed by laying the trephine biopsy rods into polyethylene embedding moulds of $12 \times 8 \mathrm{~mm}$ block size (TAAB Ltd, Aldermaston, UK), filled with fresh resin. Finally, labelled plastic cylindrical stubs $(25 \times 10 \mathrm{~mm}$; TAAB Ltd $)$ are put on top of each mould, and samples are kept at $56-60^{\circ} \mathrm{C}$ in a thermostat for 16-24 hours to allow the resin to polymerise (fig 1A).

Semithin sections ( $2 \mu \mathrm{m}$ thick) are cut from the resin blocks on a rotary microtome (for example, Slee-Mainz 4055; Slee Technik GmbH, Mainz, Germany) equipped with a cylindrical specimen holder, and using either a tungsten

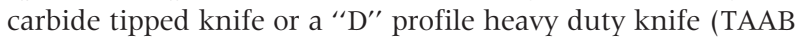
Ltd) (fig 1B). Sections are floated on an $\sim 80^{\circ} \mathrm{C}$ waterbath and mounted on silane coated or charged glass slides, such as SuperFrost Plus (Menzel GmbH, Braunschweig, Germany) or alternative adhesive slides of similar quality, which are then kept at $80^{\circ} \mathrm{C}$ for 30 minutes or at $60^{\circ} \mathrm{C}$ for between two hours and overnight to activate adhesion. Semithin sections are deplasticised by immersing them in sodium methoxide for 15 minutes. This solution is prepared by saturating methanol or ISM (industrial methylated spirit) with sodium hydroxide pellets by regular mixing, so that some pellets still remain undissolved after two days. This solution can be stored at room temperature for two months and reused up to five times. The sections are washed twice in equal parts of alcohol and xylene for three minutes, then in alcohol alone for three minutes. Endogenous peroxidases are then blocked for 20 minutes in a methanolic/0.5\% hydrogen peroxide solution. Finally, the sections are rehydrated and stained. Three $4 \mu \mathrm{m}$ thick resin sections or three $5 \mu \mathrm{m}$ thick paraffin sections are used for DNA isolation.

\section{Immunohistochemistry}

Before immunostaining, the deplasticised semithin sections (or dewaxed paraffin wax embedded sections) are exposed to wet heat at $\sim 120^{\circ} \mathrm{C}$ for two minutes in a pressure cooker (for example, Prestige 6193 or 4.5 l Tefal Clipso) for antigenic epitope retrieval. The $\mathrm{pH} 6.1$ target retrieval solution from DakoCytomation (Glostrup, Denmark), or a mixture of 0.01M Tris/0.1M EDTA, pH 9.0, is used as a retrieval solution (table 2). For a range of alternative antigen retrieval protocols see Krenacs et al. ${ }^{14}$ Immunostaining is performed in a vertical clip system (Tecan GmbH, Crailsheim, Germany), using the capillary force resulting from an approximately $150 \mu \mathrm{m}$ gap between the section and a plastic coverplate. This force permits only $100 \mu \mathrm{l}$ reagent to cover the whole glass slide until more buffer or a new reagent is added into the top funnel for replacement. The following incubation steps are carried out: (1) with primary antibodies for 60 minutes (for details see table 2); (2) with antirabbit (K4003; Dako, Glostrup, Denmark) or antimouse (K4007; Dako) immunoglobulin coupled horseradish peroxidase (HRP)-polymer conjugates (EnVision systems; Dako) for 30 minutes; (3) with a DAB (3,3'-diaminobenzidine tetrahydrochloride) hydrogen peroxide chromogen substrate kit (K3468; Dako,), for 10-15 minutes to reveal antigen bound peroxidase activity; (4) with 5\% copper sulfate for five minutes to improve the contrast of the DAB precipitate; and (5) with Gill's haematoxylin for two minutes as a counterstain. The sections are treated at room temperature and washed three times for three minutes in Tris buffered saline ( $\mathrm{pH} 7.4)$ between the incubation steps. The primary antibody is replaced by normal mouse or rabbit serum as a negative control. When internal control cells (normal leucocytes) are not available parallel sections known to contain the tested antigen serve as a positive control.

\section{Gene rearrangement analysis using PCR}

DNA is extracted from resin embedded bone marrow sections using sodium methoxide treatment for 15-20 minutes and proteinase $\mathrm{K}$ digestion without subsequent organic extraction. For immunoglobulin heavy chain gene rearrangement tests a simple pair of primers is used with the forward primer

\begin{tabular}{ll}
$\begin{array}{l}\text { Table } 1 \text { Schaefer's fixative for bone marrow trephine } \\
\text { biopsies }\end{array}$ \\
\hline Methanol & $480 \mathrm{ml}$ \\
Glucose phosphate buffer (pH 7.4) & $20 \mathrm{ml}$ \\
Neutralised formalin & $250 \mathrm{ml}$ \\
Glucose phosphate buffer (pH 7.4) & \\
$\quad$ Sodium dihydrogen phosphate & $0.96 \mathrm{~g}$ \\
Potassium dihydrogen phosphate & $0.17 \mathrm{~g}$ \\
$\quad$ Glucose & $3.08 \mathrm{~g}$ \\
$\quad$ Distilled water & Up to $100 \mathrm{ml}$ \\
Neutralised formalin & $87.5 \mathrm{ml}$ \\
Formalin ( 35\% formaldehyde) & $12.5 \mathrm{ml}$ \\
$\quad$ Distilled water & $5 \mathrm{~g}$ \\
Calcium carbonate ( $50 \mathrm{~g} / \mathrm{l})$ & $25 \mathrm{~g}$ \\
EDTA-formaldehyde for overnight decalcification & \\
Disodium EDTA dihydrate & Up to $250 \mathrm{ml}$ \\
4\% formaldehyde ( 10\% formalin) & \\
\hline
\end{tabular}

showing $(\mathrm{O})$ monoclonal $\mathrm{lgH}$ gene rearrangement with polymerase chain reaction amplification (arrow). Large lymphocytes presenting (P) villous membrane staining with anti-CD20 antibody and (R) a granular intracytoplasmic reaction with DBA-44 antibody in hairy cell leukaemia. The histogenetic origin of tumours metastatic to the bone marrow is identified by immunostaining for (S) CD79a in a diffuse large B cell lymphoma, (T) prostate specific antigen in prostate cancer, and (U) Her2/c-erbB2 in a breast cancer. Note the excellent morphology and chromatin details, in addition to the high resolution antigen localisation in all immunostained cases. (C, F-U) Show EDTA decalcified tissues. The length of the bar shown in D is equal to $50 \mu \mathrm{m}$ in $\mathrm{D}, \mathrm{K}$, L, and $\mathrm{M} ; 100 \mu \mathrm{m}$ in $\mathrm{C}$ and $\mathrm{N} ; 20 \mu \mathrm{m}$ in $\mathrm{E} ; 35 \mu \mathrm{m}$ in F; $25 \mu \mathrm{m}$ in G and $\mathrm{H} ; 70 \mu \mathrm{m}$ in I, J, and T; $30 \mu \mathrm{m}$ in $\mathrm{P}, \mathrm{R}$, and $\mathrm{S}$; and $120 \mu \mathrm{m}$ in U. 
directed at the $\mathrm{VH}$ region (FR3) and the reverse primer at the JH segment. ${ }^{15}$ For $\mathrm{T}$ cell receptor $\gamma$ chain gene rearrangement tests, triplicate aliquots of each sample are used with three forward primers (V1-8, V9, and V10-11 regions) and one reverse primer ( $\mathrm{Jl}-2$ segments). ${ }^{16}$ In all cases, 40 cycles of PCR of 30 seconds at $94^{\circ} \mathrm{C}, 30$ seconds at $56^{\circ} \mathrm{C}$, and 30 seconds at $72^{\circ} \mathrm{C}$ are performed after preheating to $94^{\circ} \mathrm{C}$. The final extension time is 10 minutes at $72^{\circ} \mathrm{C}$. DNA extracted from a B and $\mathrm{T}$ cell lymphoma is used as a positive control and a reaction without template DNA is run as a negative control. Amplified products are run on a $10 \%$ polyacrylamide gel, which is fixed in a $0.5 \%$ acetic acid, $10 \%$ ethanol solution for six minutes, impregnated in a $0.1 \%$ silver nitrate solution for 15 minutes, and developed in a $0.15 \%$ formaldehyde, $1.5 \%$ sodium hydroxide solution to be photographed under visible light. ${ }^{17}$

\section{RESULTS AND COMMENTS}

The diagnostic interpretation of bone marrow biopsies is based on histopathological tests, which are largely dependent on tissue processing from the time of obtaining the sample to the detection of target molecules. ${ }^{18}$ Crucial factors thought to influence the end result include fixation, decalcification, embedding, cutting, antigen retrieval, the specificity and sensitivity of the antibodies used, the immunodetection system used, DNA amplification, and gel detection.

Whatever fixative is used, it is crucial to start fixation if not immediately then at least within 10 minutes of the biopsy procedure. Acidic fixatives such as Bouin's, or those using mercuric chloride, such as B5 or Zenker's, offer fair cytomorphology but their value for immunohisto/cytochemistry (these terms may be used as alternatives) and particularly for DNA preservation is limited. ${ }^{19-22}$ Fixation of trephine biopsies in buffered formaldehyde has been found a useful compromise supporting, when followed by appropriate decalcification and paraffin wax embedding, both adequate morphology and the detection of proteins and nucleic acids. ${ }^{35-8}$ The addition of calcium carbonate and glucose to the fixative in the Schaefer's formula (table 1) helps to improve chromatin details and prevents shrinkage artefacts (fig 1), making this fixative preferable for bone marrow histopathology. ${ }^{13}$

To ensure structural and molecular preservation it is also essential to complete fixation before starting decalcification. ${ }^{23}$ If there is an increased amount of cortical bone it is necessary to extend fixation and decalcification beyond the usual six to 10 hour and 16-24 hour ranges, respectively. The pressure on pathologists to speed up diagnostic reporting has led some laboratories to use acid based decalcifiers. However, both inorganic acids (such as hydrochloric acid) and organic acids (such as formic acid at $5-10 \%$ concentration) can damage tissue architecture and stainability. ${ }^{23}$ Acid treatment requires endpoint checking of calcium removal to avoid tissue damage, and it may also damage antigenic epitopes and DNA. In contrast, decalcification of properly fixed trephine biopsy specimens in 10\% neutral EDTA solution for 16-24 hours at $60^{\circ} \mathrm{C}$ usually allows sufficient elimination of calcium from tiny bone trabecules without noticeable morphological and molecular damage. Moreover, EDTA as one of the most efficient antigen retrieval agents may add to the beneficial effect of heat induced epitope retrieval treatment used before immunohistochemistry. ${ }^{24}$ Formaldehyde postfixation during decalcification may be crucial in preserving tissue morphology after heat induced epitope retrieval.

For bone marrow diagnosis, some laboratories prefer plastic embedded semithin sections, because they provide superior cell and tissue morphology to paraffin wax embedded sections. ${ }^{9-11}{ }^{13}$ In addition, the hard resin allows cutting of sections without eliminating tissue calcium, which may shorten tissue processing and is better suited to the detection of fine haemosiderin particles with a Perls' stain or the detection of Auer rods with a May-Grünwald Giemsa stain (fig 1D, E). Nevertheless, even moderate decalcification helps to preserve bone trabeculae and the surrounding endosteal haemopoietic margin during staining procedures; thus, recently we have been using EDTA treatment. However, resin embedding may have inherent limitations, such as the need for special instruments, tools, and conditions for resin processing and cutting. Furthermore, reactive resin monomers may add to the antigen masking effect of the fixative, and most acrylic resins cannot be removed from the sections, which may prevent immunoreagents from accessing their targets. Therefore, laboratories requiring superb semithin resin histology may divide trephine biopsies and use resin sections for histology and paraffin embedded or frozen sections for immunohistochemistry. ${ }^{11}{ }^{13}$ Alternatively, resin protocols can be adjusted to the requirements of antigen and even DNA detection. ${ }^{25-28}$ We have run parallel resin and paraffin wax embedding for bone marrow trephine biopsy specimens. Paraffin wax embedded specimens may be used for consulting with centres not familiar with resin technology and for routine DNA extraction. Paraffin wax embedded tissues may also provide a safe stock for research in case an important new marker is not detectable in resin sections. Durcupan ACM is an aromatic polyepoxide resin of uniform hardening character and low risk of tissue shrinkage ${ }^{29}$ (fig l). Serial sections can be cut from the resin blocks using an ordinary rotary microtome and heavy duty cutting knives and the sections are fully rehydrated after etching.

Wet heat induced epitope retrieval is thought to loosen crosslinks formed by formaldehyde in and around antigenic epitopes, allowing them to be exposed later by immunoreagents. ${ }^{30}{ }^{31}$ Usually, more efficient antigen retrieval buffers, such as the high pH Tris/EDTA buffer, have a higher risk of damaging section integrity. Therefore, firm and standard section adhesion provided by adhesive glass slides, such as SuperFrost Plus, is essential for efficient antigen detection. We have continuously refined our antigen retrieval protocol to achieve sensitive and reproducible antigen detection in bone marrow semithin sections (fig l). If manually stained, the two step EnVision-HRP conjugate system saves up to several technician weeks each year compared with a three step ABC-HRP detection, without compromising reaction sensitivity. ${ }^{32}$ The use of a standard DAB chromogen substrate kit and copper sulfate contrasting are also important parts of a reliable protocol. ${ }^{33}$ Sensitivity is a specific issue here, in view of the fact that semithin sections contain significantly fewer antigens than regular paraffin wax embedded sections.

\section{"Wet heat induced epitope retrieval is thought to loosen crosslinks formed by formaldehyde in and around antigenic epitopes, allowing them to be exposed later by immunoreagents"}

During the diagnostic process, deplasticised semithin sections are regularly stained with haematoxylin and eosin for routine histology. Giemsa, periodic acid Schiff, Gomori's silver stain, or Perls' stain are used for specific components, on request. Based on clinical data and assessment of cytomorphology and histotopography, targeted immunohistochemical marker analysis is performed using a well referenced panel of antibodies (table 2). Improved cytomorphology provided by semithin sections greatly facilitates making an initial provisional diagnosis. In some cases, paraffin wax embedded sections, peripheral blood smears, or touch prints may also be immunostained. Antigen receptor gene rearrangement assays may also be initiated after immunostaining. 
Table 2 Immunohistochemical markers useful in the diagnostic interpretation of Durcupan embedded bone marrow trephine biopsies

\begin{tabular}{|c|c|c|c|c|c|}
\hline Antibody/clone & Source & Dilution & HIER & Tissue/cell specificity & Diagnostic note \\
\hline $\mathrm{m}-\mathrm{CD} 1 \mathrm{a} ; \mathrm{O} 10$ & Dako & $1 / 100$ & TRS & Cortical thymocytes, activated interdigitating cells & Langerhans cell histiocytosis \\
\hline $\mathrm{m}-\mathrm{CD} 2 ; \mathrm{AB75}$ & NovoCastra & $1 / 50$ & TRS & Thymocytes, T cells, NK cells & $\mathrm{TCL}, \mathrm{NK}-\mathrm{CL}$ \\
\hline $\mathrm{r}-\mathrm{CD} 3 \epsilon$; or & Dako & $1 / 200$ & $T / E$ & $\mathrm{~T}$ cells & TCL, ALL \\
\hline rmo-CD3; SP7 & NeoMarkers & $1 / 100$ & $\mathrm{~T} / \mathrm{E}$ & Some activated NK cells & \\
\hline $\mathrm{m}-\mathrm{CD} 4 ; 4 \mathrm{~B} 12$ & NeoMarkers & $1 / 20$ & $\mathrm{~T} / \mathrm{E}$ & Thymocytes, helper T cells & \\
\hline $\mathrm{r}-\mathrm{CD} 5$ & NeoMarkers & $1 / 300$ & $\mathrm{~T} / \mathrm{E}$ & T cells; B cell subset & B-CLL, MCL \\
\hline $\mathrm{m}-\mathrm{CD} 8 ; \mathrm{C} 8 / 114 \mathrm{~B}$ & Dako & $1 / 100$ & TRS & Cytotoxic cells, T cells & \\
\hline $\mathrm{m}-\mathrm{CD} 10 ; 56 \mathrm{C} 6$ & NovoCastra & $1 / 20$ & $\mathrm{~T} / \mathrm{E}$ & CALLA, pre-B cells, GC B cells & $\mathrm{ALL}, \mathrm{FL}$ \\
\hline m-CD15; C3D-1 & Dako & $1 / 30$ & TRS & Myelomonocytic cells (lgM type) & $\begin{array}{l}\text { Hodgkin's } \\
\text { R-S cells }\end{array}$ \\
\hline$m-C D 20 ; \mathrm{L}-26$ & Dako & $1 / 200$ & TRS & B cells, except lymphoblasts and plasma cells & \\
\hline $\mathrm{m}-\mathrm{CD} 23 ; 1 \mathrm{~B} 12$ & NovoCastra & $1 / 40$ & TRS & B cell subsets, FDCs & $\mathrm{B}-\mathrm{CLL}$ \\
\hline $\mathrm{m}-\mathrm{CD} 30 ; \mathrm{MP}-1$ & NovoCastra & $1 / 50$ & TRS & Some activated lymphocytes & $\begin{array}{l}\text { ALCL, Hodgkin's } \\
\text { R-S cell }\end{array}$ \\
\hline $\mathrm{m}-\mathrm{CD} 31 ; \mathrm{JC} 70 \mathrm{~A}$ & Dako & $1 / 50$ & TRS & $\begin{array}{l}\text { PECAM-1, endothelial cells, platelets, } \\
\text { megakaryocytes }\end{array}$ & \\
\hline m-CD34; QBEnd10 & Dako & $1 / 50$ & TRS & Haemopoietic stem cells, endothelial cells & Precursor cells \\
\hline $\mathrm{m}-\mathrm{CD} 38 ; \mathrm{SPC} 32$ & NovoCastra & $1 / 2000$ & $T / E$ & Early B cells, plasma cells & $M M, A L L$ \\
\hline m-CD43; DF-T1 & NovoCastra & $1 / 50$ & TRS & $\mathrm{T}$ cells, $\mathrm{B}$ cell subsets & $\mathrm{B}-\mathrm{CLL}$ \\
\hline $\mathrm{m}-\mathrm{CD} 45 ; 2 \mathrm{~B} 11+\mathrm{PD} 7 / 26$ & Dako & $1 / 100$ & TRS & Most leucocytes of lymphoid or myeloid origin & \\
\hline $\mathrm{m}-\mathrm{CD} 56 ; 1 \mathrm{~B} 6$ & NovoCastra & $1 / 50$ & TRS & $\mathrm{N}-\mathrm{CAM}, \mathrm{NK}$ cells, T cell subsets & $\mathrm{MM}, \mathrm{NK}-\mathrm{CL}$ \\
\hline $\mathrm{m}-\mathrm{CD} 61 ; 2 \mathrm{f} 2$ & NovoCastra & $1 / 100$ & TRS & Megakaryocytes, platelets & CMPD \\
\hline $\mathrm{m}-\mathrm{CD} 68 ; \mathrm{PG}-\mathrm{M} 1$ & Dako & $1 / 100$ & TRS & Monocytes, macrophages & AML FAB M4-5; CML \\
\hline $\mathrm{m}-\mathrm{CD} 79 \mathrm{a} ; \mathrm{JCB} 117$ & Dako & $1 / 50$ & TRS & All B cells including pre-B cells and plasma cells & $\mathrm{B}-\mathrm{CLL}, \mathrm{ALL}, \mathrm{MM}$ \\
\hline$r-C D 117$ & Dako & $1 / 300$ & TRS & Mast cells, myeloblasts (c-kit) & AML, mastocytosis \\
\hline m-CD138; MI15 & Dako & $1 / 100$ & TRS & Syndecan-1, plasma cells & $M M$ \\
\hline $\mathrm{m}-\mathrm{CD} 163 ; 10 \mathrm{D} 6$ & NovoCastra & $1 / 100$ & TRS & Activated monocytes, macrophages & \\
\hline $\mathrm{m}-\mathrm{CD} 235 \mathrm{a} ; \mathrm{JC} 159$ & Dako & $1 / 100$ & TRS & Glycophorin A, erythroid cell & AML, CMPD \\
\hline $\mathrm{m}-\mathrm{CD} 246 ;$ ALK-1 & Dako & $1 / 100$ & TRS & ALK protein, $t(2 ; 5)$ & $\mathrm{ALCL}$ \\
\hline $\begin{array}{l}\text { m-Androgen receptor; } \\
\text { AR441 }\end{array}$ & Dako & $1 / 100$ & TRS & Glandular and ductal prostate epithelium & Prostate cancer metastasis \\
\hline $\mathrm{r}$-Chromogranin A & Dako & $1 / 800$ & TRS & Neuroendocrine cells & Metastasis \\
\hline $\mathrm{r}$-C-erbB2/Her2 & Dako & $1 / 100$ & TRS & EGF-R family, breast cancer & Metastasis \\
\hline rmo-Cyclin D1; SP1 & NeoMarkers & $1 / 100$ & $T / E$ & Cell cycle regulation & $M C L / t(11 ; 14), M M$ \\
\hline $\begin{array}{l}\text { m-Cytokeratin 7; OV-TL } \\
12 / 30\end{array}$ & Dako & $1 / 100$ & $\mathrm{~T} / \mathrm{E}$ & Ductal and glandular epithelium (e.g. breast) & Breast cancer metastasis \\
\hline m-Cytokeratin $20 ; \mathrm{K}_{\mathrm{s}} 20.8$ & Dako & $1 / 100$ & $T / E$ & Transitional and gastrointestinal epithelium & Colon cancer metastasis \\
\hline $\begin{array}{l}\text { m-Cytokeratin pan; AEl/ } \\
\text { AE3 }\end{array}$ & Dako & $1 / 200$ & $T / E$ & Pan-epithelial marker & Carcinoma metastasis \\
\hline m-EBV-LMP-1; CS1-4 & Dako & $1 / 100$ & TRS & EBV latent infection & Hodgkin's R-S cell \\
\hline $\mathrm{m}-\mathrm{DBA}-44$ & Dako & $1 / 100$ & TRS & B cell subsets (IgM type) & Hairy cell leukaemia \\
\hline m-Desmin; D33 & Dako & $1 / 100$ & TRS & Muscle cells (skeletal, smooth, and cardiac) & $\begin{array}{l}\text { Rhabdomyosarcoma } \\
\text { metastasis }\end{array}$ \\
\hline m-EMA; E29 & Dako & $1 / 100$ & TRS & Epithelial membrane antigen, plasma cells & Carcinoma metastasis \\
\hline $\begin{array}{l}\text { m-Oestrogen receptor; } \\
6 \mathrm{~F} 11\end{array}$ & NovoCastra & $1 / 100$ & TRS & Breast epithelium & Breast cancer metastasis \\
\hline m-GCDFP15; 23A3 & NovoCastra & $1 / 50$ & TRS & Ductal epithelium, breast and salivary glands & Carcinoma metastasis \\
\hline m-Granzyme B; GrB-7 & Dako & $1 / 100$ & TRS & $\begin{array}{l}\text { Cytotoxic T cells, NK cells, large granular } \\
\text { lymphocytes }\end{array}$ & LGL leukaemia \\
\hline r-Haemoglobin & Dako & $1 / 500$ & TRS & Erythroblasts, erythrocytes & CMPD, MDS, AML \\
\hline m-Melanosome; HMB-45 & Dako & $1 / 100$ & TRS & Melanocytic cells & Melanoma metastasis \\
\hline $\lg H(r-\alpha,-\gamma,-\mu)$ & Dako & $\begin{array}{l}\lg A, 1 / 800 \\
\lg G, 1 / 10000\end{array}$ & TRS & Plasmacytoid cells, plasma cells, immunocytes & $M M$, immunocyłoma \\
\hline $\lg L(r-\kappa,-\lambda)$ & Dako & $1 / 100000$ & TRS & B cells: perinuclear/membrane or cytoplasmic & B cell clonality \\
\hline m-Ki67; Mib-1 & Dako & $1 / 100$ & TRS & Cell cycle (G1, S, G2, M) & Proliferation \\
\hline r-lysozyme & Dako & $1 / 2000$ & TRS & Myeloid cells, histiocytes & AML, CML \\
\hline r-Myeloperoxidase & Dako & $1 / 5000$ & TRS & Myelopoietic cells & AML, CML \\
\hline r-PSA or $\mathrm{m}$-PSA; ER-PR8 & Dako & $1 / 100$ & TRS & Prostate secretory and ductal epithelium & Prostate cancer metastasis \\
\hline$r-S 100(A B)$ & Dako & $1 / 500$ & TRS & Neoplastic melanocytes, Langerhans cells, fat cells & Melanoma metastasis \\
\hline $\mathrm{m}$-Spectrin; RBC2/3D5 & NovoCastra & $1 / 100$ & $\mathrm{~T} / \mathrm{E}$ & Erythroid cells & CMPD, AML \\
\hline$r$-TdT & Dako & $1 / 50$ & $\mathrm{~T} / \mathrm{E}$ & Lymphoid precursor cells & B/T-ALL \\
\hline $\mathrm{m}-\mathrm{TF}-1 ; 8 \mathrm{G} 7 \mathrm{G} 3 / 1$ & Dako & $1 / 100$ & TRS & Lung and thyroid epithelia & $\begin{array}{l}\text { Lung, or thyroid cancer } \\
\text { metastasis }\end{array}$ \\
\hline r-VWF (FVIII related) & Dako & $1 / 1000$ & TRS & Endothelial cells, megakaryocytes & MPD, CMPD \\
\hline
\end{tabular}

$\mathrm{ALCL}$, anaplastic large cell lymphoma; $\mathrm{ALL}$, acute lymphoblastic leukaemia; $\mathrm{AML}$, acute myeloid leukaemia; $\mathrm{B} 5$, mercuric chloride containing fixative; $\mathrm{B}$ - $\mathrm{CLL}, \mathrm{B}$ cell chronic lymphocytic leukaemia/small lymphocytic lymphoma; CALLA, common acute leukaemia lymphoma antigen (CD10); CML, chronic myeloid leukaemia; CMPD, chronic myeloproliferative disease; EBV-LMP-1, Epstein-Barr virus latent membrane protein 1; EMA, epithelial membrane antigen; FDC, follicular dendritic cell; FL, follicular lymphoma; GC, germinal centre; HIER, heat induced epitope retrieval; lgH/L, immunoglobulin heavy/light chain; LGL, large granular lymphocyte; $m$, mouse monoclonal immunoglobulin; MCL, mantle cell lymphoma; MDS, myelodysplastic syndrome; MM, multiple myeloma; MPD, myeloproliferative disease; N-CAM, neural cell adhesion molecule; NK-CL, natural killer cell lymphoma; PECAM-1, platelet endothelial cell adhesion molecule-1 ; PSA, prostate specific antigen; r, rabbit polyclonal immunoglobulin; rmo, rabbit monoclonal immunoglobulin; R-S cell, Reed-Sternberg cell; TCL, T cell lymphoma; TdT, terminal deoxynucleotidyl transferase; T/E, Tris EDTA pH 9; TRC, T cell receptor; TRS, target retrieval solution pH 6.1; TTF-1, thyroid transcription factor 1; vWF, von Willebrand factor.

Dako, Glostrup, Denmark; NeoMarkers, Freemont, California, USA; NovoCastra, Newcastle, UK. 
Table 3 Comparison between Durcupan and paraffin wax processing of bone marrow trephine biopsies

\begin{tabular}{|c|c|c|c|c|c|c|}
\hline & \multicolumn{3}{|l|}{ Durcupan sections } & \multicolumn{3}{|c|}{ Paraffin wax embedded sections } \\
\hline & Mode & Timing (hours) & $\begin{array}{l}\text { Cost/case } \\
(€)\end{array}$ & Mode & Timing & $\begin{array}{l}\text { Cost/case } \\
(€)\end{array}$ \\
\hline Fixation & $4 \%$ buffered formaldehyde & $\begin{array}{l}6-10 \mathrm{~h} \text { 1st day, or until } \\
\text { arrival }\end{array}$ & $\sim 1.2$ & $4 \%$ buffered formaldehyde & $\begin{array}{l}\text { 6-10 h 1st day, } \\
\text { or until arrival }\end{array}$ & $\sim 1.2$ \\
\hline Decalcification & $\begin{array}{l}10 \% \text { EDTA at } 60^{\circ} \mathrm{C} \text { (with } \\
4 \% \text { formaldehyde) }\end{array}$ & $16-24$ h, 1st night & $\sim 1.2$ & $\begin{array}{l}10 \% \text { EDTA at } 60^{\circ} \mathrm{C} \text { (with } 4 \% \\
\text { formaldehyde) }\end{array}$ & $\begin{array}{l}16-24 \mathrm{~h}, 1 \mathrm{st} \\
\text { night }\end{array}$ & $\sim 1.2$ \\
\hline $\begin{array}{l}\text { Processing } \\
\text { (dehydration) }\end{array}$ & $\begin{array}{l}\text { Ethanol (IMS) series and } \\
\text { acetone }\end{array}$ & 2 h 2nd day & $\sim 1$ & $\begin{array}{l}\text { Ethanol (IMS) series and } \\
\text { xylene }\end{array}$ & 3 h 2nd day & $\sim 1$ \\
\hline Embedding & $\begin{array}{l}\text { Durcupan } A C M \text { resin } \\
\text { (hardening at } 60^{\circ} \mathrm{C} \text { ) }\end{array}$ & 16-24 h 2nd night & $\sim 5$ & $\begin{array}{l}\text { Paraplast (for infiltration and } \\
\text { block making) }\end{array}$ & 3 h 2nd day & $\sim 1.8$ \\
\hline $\begin{array}{l}\text { Cutting and } \\
\text { section mounting } \\
\text { ( } 1 \text { section for } H \& E \text { ) }\end{array}$ & $\begin{array}{l}\text { Tungsten-carbide knife (on } \\
\text { rotary microtome) + } \\
\text { activation of adhesion }\end{array}$ & $\begin{array}{l}0.3 \mathrm{~h} / \mathrm{block} / 6 \text { sections } \\
3 \mathrm{rd} \text { night }\end{array}$ & $\sim 6^{*}$ & $\begin{array}{l}\text { Disposable blade (on rotary } \\
\text { microtome) + activation of } \\
\text { adhesion }\end{array}$ & $\begin{array}{l}0.2 \mathrm{~h} / \mathrm{block} / 6 \\
\text { sections } 3 \mathrm{rd} \\
\text { night }\end{array}$ & $\sim 2$ \\
\hline Rehydration & Sodium methoxide & $0.5 \mathrm{~h}$ 4th day & $\sim 1$ & Xylene/ethanol series & $0.4 \mathrm{~h}$ 4th day & $\sim 2$ \\
\hline $\begin{array}{l}\text { Immunohistochemistry } \\
\text { (5 sections/case) }\end{array}$ & $\begin{array}{l}\text { Standard antibody panel } \\
\text { (table 2), HIER-EnVision }\end{array}$ & 3 h 4 th day & $\sim 10$ & $\begin{array}{l}\text { Standard antibody panel } \\
\text { (table 2), HIER-EnVision }\end{array}$ & $3 \mathrm{~h}$ 4th day & $\sim 10$ \\
\hline $\begin{array}{l}\text { PCR technique } \\
\text { (excluding DNA } \\
\text { isolation) }\end{array}$ & $\begin{array}{l}\text { Standard amplification and } \\
\text { detection }\end{array}$ & 6 h occasionally & $(\sim 10)$ & $\begin{array}{l}\text { Standard amplification and } \\
\text { detection }\end{array}$ & 6 h occasionally & $\sim 10$ \\
\hline \multicolumn{3}{|l|}{ Sum total } & 25.4 & \multicolumn{2}{|l|}{ Sum total } & 19.2 \\
\hline
\end{tabular}

Durcupan embedding following formaldehyde fixation, with or without decalcification, permits the detection of a wide range of antigens of diagnostic interest in the bone marrow (table 2). These include: (1) lineage restricted antigens identifying haemopoietic and lymphoid cells (for example, CD2, CD3, CD20, CD61, CD79a, haemoglobin, myeloperoxidase); (2) markers indicating cell differentiation stages, such as immature (for example, CDla, CD10, CD34, CD38, CD117, and TdT), middle stage (for example, CD20), or late differentiation (for example, CD138); (3) markers of clonal lymphoid populations (immunoglobulin light and heavy chains; or monoclonal gene rearrangement by PCR); and (4) markers not detected normally in archived bone marrow indicating lymphoreticular disease (for example, CD23, CD30, CD246, cyclin-D1, Epstein-Barr virus latent membrane protein, and DBA-44), or metastatic tumours, such as carcinoma (for example, pancytokeratin and epithelial membrane antigen), melanoma (for example, HMB-45), paediatric small cell tumours (for example, desmin and chromogranin A), or even specific sites of metastatic carcinoma (for example, oestrogen receptor, thyroid transcription factor 1 , and prostate specific antigen). Figure 1 shows some examples.

The same protocol can also be used to detect a range of other antigens in Durcupan embedded tissues-for example, peptide hormones and intermediate filaments. ${ }^{34}$ In addition, aliphatic epoxy resins such as those based on the Epon 812 formula can be used for immunohistochemistry in a similar way to that described here. ${ }^{27}$ Before the era of heat induce antigen retrieval, we exploited the etching effect of sodium methoxide on epoxy resins (thought to be the result of transesterification and/or oxidation ${ }^{29}$ ) for retrieving antigens and enhancing the sensitivity of immunodetection in paraffin wax embedded sections. ${ }^{35}$ Recently, this approach has been advocated as a non-heat mediated antigen retrieval technique. $^{36}$

The advantage of using Durcupan over an acrylate resin is that its processing does not require special conditions (such as ultraviolet light) and the rehydration of sections needs no modification of the original resin formula, which may be necessary when using acrylates. ${ }^{25} 28$ The benefit of Durcupan over paraffin wax embedding includes less shrinkage artefact, better cytomorphology and cytotopography, easier indication of targeted immunocytochemistry, improved resolution of photographic archives, and more efficient utilisation of the tissue (at least three times as many sections can be cut from the same biopsy specimen). Conversely, there are drawbacks to Durcupan embedding related to the extra costs (resin, special cutting knife, sodium methoxide) and the need for embedding and cutting skills. The diagnostic turnaround time does not differ greatly between the two systems. Table 3 summarises the comparison between Durcupan and paraffin wax processing of bone marrow trephines. This resin technique may be worth introducing into laboratories where several hundred bone marrows are examined each year and where the budget for bone marrow histopathology can be extended by $\sim 30 \%$ compared with that for routine paraffin wax processing.

The Durcupan resin processing of bone marrow trephine biopsies described here offers very satisfactory histomorphology and cytomorphology, sensitive and reliable immunodetection of an ever growing number of antigens, and reliable DNA analysis. Considering the advantages and disadvantages in comparison with paraffin wax embedded sections, this resin technology can provide a powerful support in the diagnostic interpretation and research into primary and secondary disorders of the bone marrow.

\section{ACKNOWLEDGEMENTS}

This diagnostic system is run in close cooperation with haematologists of our regional centre-Professors G Varga and Z Borbenyi, and Dr K Piukovics-whose contribution is greatly appreciated by the authors. We are also grateful to Mrs K Szekeres Danyine, A Sarro, and M Labdy for their skilful technical assistance. This work is supported by grants ETT 549/2003 and ETT 049/2003 from the Hungarian Ministry of Health.

\section{Authors' affiliations}

T Krenacs, E Bagdi, E Stelkovics, L Bereczki, L Krenacs, Laboratory of Tumour Pathology and Molecular Diagnostics, Institute for

Biotechnology, Bay Zoltan Foundation for Applied Research, H-6726 Szeged, Hungary 


\section{REFERENCES}

1 Bain BJ. Bone marrow trephine biopsy. J Clin Pathol 2001:54:737-42.

2 Sah SP, Matutes E, Wotherspoon AC, et al. A comparison of flow cytometry bone marrow biopsy, and bone marrow aspirates in the detection of lymphoid infiltration in B cell disorders. J Clin Pathol 2003;56:129-32.

3 Thiele J, Zirbes TK, Kvasnicka HM, et al. Focal lymphoid aggregates (nodules) in bone marrow biopsies: differentiation between benign hyperplasia and malignant lymphoma-a practical approach. I Clin Pathol 1999;52:294-300.

4 Jaffe ES, Harris NL, Stein $\mathrm{H}$, et al. Pathology and genetics of tumours of haematopoietic and lymphoid tissues. In: World Health Organization classification of tumours. Lyon: IARC Press, 2001.

5 Werner M, Kaloutsi, Walter K, et al. Immunohistochemical examination of routinely processed bone marrow biopsies. Pathol Res Pract 1992; 188:707-13.

6 Thiele J, Schmitz B, Fuch R, et al. Detection of the bcr/abl gene in bone marrow macrophages in CML and alterations during interferon therapy-a fluorescent in situ hybridisation study on trephine biopsies. J Pathol 1998; 186:331-5.

7 Toth B, Wehrmann M, Kaiserling E, et al. Immunophenotyping of acute lymphoblastic leukaemia in routinely processed bone marrow biopsy specimens. J Clin Pathol 1999;52:688-92.

8 Le Maitre CL, Byers RJ, Liu Jin JA, et al. Dual colour FISH in paraffin wax embedded bone trephines for identification of numerical and structural chromosomal abnormalities in acute myeloid leukaemia and myelodysplasia. J Clin Pathol 2001;54:730-3.

9 Islam A, Frisch B. Plastic embedding in routine histology. I: Preparation of semithin resin sections of undecalcified marrow cores. Histopathology 1985:9:1263-74.

10 Burkhardt R, Frisch B, Bart R. Bone biopsy in haematological disorders. J Clin Pathol 1982;35:257-84.

11 Thaler J, Dietze O, Denz H, et al. Bone marrow diagnosis in lymphoproliferative disorders: comparison of results obtained from conventional histomorphology and immunohistology. Histopathology 1991; 18:495-504

12 Gatter KC, Heryet A, Brown DC, et al. Is it necessary to embed bone marrow biopsies in plastic for haematological diagnosis? Histopathology 1987:11:1-7.

13 In: Frisch B, Bartl R, eds. Biopsy interpretation of bone and bone marrow. London: Arnold (Oxford University Press), 1999.

14 Krenacs L, Krenacs T, Raffeld M. Antigen retrieval for immunohistochemical reactions in routinely processed paraffin sections. In: Javois LC, ed. Methods in molecular biology, Vol. 115. Immunocytochemical methods and protocols, 2nd ed. Totowa, NJ: Humana Press, 1999:85-93.

15 Diss TC, Pan LX, Peng $H$, et al. Sources of DNA for detecting $B$ cell monoclonality using PCR. J Clin Pathol 1994;47:493-6.

16 Diss TC, Watts M, Pan LX, et al. The polymerase chain reactions in the demonstration of monoclonality in T cell lymphomas. J Clin Pathol 1995; $48: 1045-50$

17 Gonzales M, Gonzales D, Lopez-Perez R, et al. Heteroduplex analysis of VD amplified segments from rearranged lgH genes for clonality assessment in Bcell non-Hodgkin's lymphoma. A comparison between different strategies. Haematologica 1999;84:779-84.

18 Miller K. Immunocytochemical techniques. In: Bancroft JD, Gamble M, eds. Theory and practice of histological techniques, 5th ed. London: Churchill Livingstone, 2002:421-64.

19 Gaulier A, Fourcade C, Szekeres Gy, et al. Bone marrow one step fixationdecalcification in Lowy FMA solution: an immunohistological and in situ hybridization study. Pathol Res Pract 1994;190:1 149-61.
20 Gala JL, Chenut F, Hong KB, et al. A panel of antibodies for the immunostaining of Bouin's fixed bone marrow trephine biopsies. J Clin Pathol 1997;50:521-4.

21 Vassallo J, Pinto GA. Antibody panel in diagnosis of lymphoid neoplasms (letter to Galla et al. 1997;50: 521-24; and authors response). J Clin Pathol 1998;51:638-9.

22 Guillou L, Coindre J, Gallagher G, et al. Detection of the synovial sarcoma translocation $\mathrm{t}(\mathrm{X} ; 18)$ (SYT;SSX) in paraffin-embedded tissues using reverse transcriptase-polymerase chain reaction: a reliable and powerful diagnostic tool for pathologists. A molecular analysis of 221 mesenchymal tumors fixed in different fixatives. Hum Pathol 2001;32:105-12.

23 Callis GM. Bone. In: Bancroft JD, Gamble M, eds. Theory and practice of histological techniques, 5th ed. London: Churchill Livingstone, 2002:269-301

24 Pileri SA, Roncador G, Ceccarelli C, et al. Antigen retrieval techniques in immunohistochemistry: comparison of different methods. J Pathol 1997:183:116-23.

25 Bernhards J, Weitzer B, Werner $M$, et al. A new histological embedding method by low-temperature polymerisation of methyl methacrylate allowing immuno- and enzyme histochemical studies on semithin sections of undecalcified bone marrow biopsies. Histochemistry 1992;98: 145-54

26 Fend $F$, Gschwendtner A, Gredler $E$, et al. Detection of B cell populations in decalcified, plastic embedded bone marrow biopsies with the polymerase chain reaction. Am J Clin Pathol 1994:102:850-5.

27 McCluggage WG, Roddy S, Whiteeside C, et al. Immunohistochemical staining of plastic embedded bone marrow trephine biopsy specimens after microwave heating. J Clin Pathol 1995;48:840-4.

28 Blythe D, Hand NM, Jackson P, et al. Use of methyl methacrylate resin for embedding bone marrow trephine biopsy specimens. I Clin Pathol 1997;50:45-9.

29 Causton BE. The choice of resins for electron immunocytochemistry. In: Polak JM, Varndell IM, eds. Immunolabeling for electron microscopy. Amsterdam: Elsevier, 1984:29.

30 Cattoretti G, Pileri S, Parravichini C, et al. Antigen unmasking on formalinfixed, paraffin-embedded tissue sections. J Pathol 1993;171:83-98.

31 Shi S-R, Gu J, Turrens JF, et al. Development of the antigen retrieval technique: philosophical and theoretical bases. In: Shi S-R, Gu J, Taylor CR, eds. Antigen retrieval techniques: immunohistochemistry and molecular morphology. Natick, MA: Biotechniques Books Publications, Eaton Publishing, 2000:17-39.

32 Kammerer U, Kapp M, Gassel AM, et al. A new rapid immunohistochemical staining technique using the EnVision antibody complex. J Histochem Cytochem 2001;49:623-30.

33 Hsu SM, Soban E. Color modification of diaminobenzidine (DAB) precipitation by metallic ions and its application for double immunohistochemistry. J Histochem Cytochem 1982;30:1079-82.

34 Krenacs T, Krenacs L, Bozoky B, et al. Double and triple immunocyto-chemical labelling at the light microscopic level in histopathology. Histochem J 1990;22:530-6.

35 Krenacs T, Stiller D, Krenacs L, et al. Sarcoplasmic reticulum (SR) $\mathrm{Ca}^{2+}$ ATPase as a marker of muscle cell differentiation: immunohistochemical investigations of rhabdomyosarcomas and enhancement of the immunostaining after sodium methoxide pretreatment. Acta Histochem 1990;88:159-66.

36 Shi S-R, Gu J, Kalra KL, et al. Antigen retrieval technique: a novel approach to immunohistochemistry on routinely processed tissue sections. Cell Vision $1995 ; 2: 6-22$ 